medRxiv preprint doi: https://doi.org/10.1101/2020.05.19.20107391; this version posted May 26, 2020. The copyright holder for this preprint (which was not certified by peer review) is the author/funder, who has granted medRxiv a license to display the preprint in perpetuity.

All rights reserved. No reuse allowed without permission.

\title{
Syndromic Surveillance for COVID-19 in Canada
}

Lauren Lapointe-Shaw MDCM PhD ${ }^{1,2}$, Benjamin Rader MPH ${ }^{3,4}$, Christina M. Astley MD ScD ${ }^{3,5}$, Jared B. Hawkins MMSc PhD ${ }^{3,5}$, Deepit Bhatia MPH ${ }^{1}$, William J. Schatten MA ${ }^{6}$, Todd C. Lee MD MPH ${ }^{7}$, Jessica J. Liu MD MSc ${ }^{1,2}$, Noah M. Ivers MD PhD ${ }^{8,9}$, Nathan M. Stall MD ${ }^{2,10}$, Effie Gournis MPH MSc ${ }^{11}$, Ashleigh R. Tuite PhD MPH ${ }^{12}$, David N. Fisman MD MPH $\mathrm{MP}^{2,12}$, ${ }^{*}$ Isaac I. Bogoch MD SM ${ }^{1,2}$, *John S. Brownstein $\mathrm{PhD}^{3,5}$

1. Department of Medicine, University Health Network, Toronto, Canada

2. Department of Medicine, University of Toronto, Toronto, Canada

3. Computational Epidemiology, Boston Children's Hospital, Boston, U.S.A.

4. Department of Epidemiology, Boston University, Boston, U.S.A.

5. Department of Pediatrics, Harvard Medical School, Boston, U.S.A.

6. Forum Research, Toronto, Canada

7. Department of Medicine, McGill University Health Centre, Montreal, Canada

8. Department of Family and Community Medicine, University of Toronto, Toronto, Canada

9. Department of Family Medicine, Women's College Hospital, Toronto, Canada

10. Department of Medicine, Sinai Health System, Toronto, Canada

11. Toronto Public Health, Toronto, Canada

12. Dalla Lana School of Public Health, University of Toronto, Toronto, Canada

${ }^{*}$ co-last authors

\section{ABSTRACT}

Background: Syndromic surveillance through web or phone-based polling has been used to track the course of infectious diseases worldwide. Our study objective was to describe the characteristics, symptoms, and self-reported testing rates of respondents in three different COVID-19 symptom surveys in Canada.

Methods: Data sources consisted of two distinct Canada-wide web-based surveys, and phone polling in Ontario. All three sources contained self-reported information on COVID-19 symptoms and testing. In addition to describing respondent characteristics, we examined symptom frequency and the testing rate among the symptomatic, as well as rates of symptoms and testing across respondent groups.

Results: We found that $1.6 \%$ of respondents experienced a symptom on the day of their survey, $15 \%$ of Ontario households had a symptom in the previous week, and $44 \%$ of Canadawide respondents had a symptom in the previous month over March-April 2020. Across the three surveys, SARS-CoV-2-testing was reported in $2-9 \%$ of symptomatic responses. Women, younger and middle-aged adults (versus older adults) and Indigenous/First nations/Inuit/Métis were more likely to report at least one symptom, and visible minorities were more likely to report the combination of fever with cough or shortness of breath.

Interpretation: The low rate of testing among those reporting symptoms suggests significant opportunity to expand testing among community-dwelling residents of Canada. Syndromic surveillance data can supplement public health reports and provide much-needed context to gauge the adequacy of current SARS-CoV-2 testing rates. 
medRxiv preprint doi: https://doi.org/10.1101/2020.05.19.20107391; this version posted May 26, 2020. The copyright holder for this preprint (which was not certified by peer review) is the author/funder, who has granted medRxiv a license to display the preprint in perpetuity.

\section{BACKGROUND}

While SARS-CoV-2 has rapidly spread globally, ascertaining its true incidence remains a challenge. ${ }^{1,2}$ This is because a large proportion of those infected (20-75\%) are minimally symptomatic or asymptomatic. ${ }^{3,4}$ Further, in many regions only those with severe illness or identified as a priority group are tested, and thus eligible for laboratory test-based confirmation. ${ }^{5}$ Until a rapid test is widely available or barriers to diagnostic testing in Canada are lowered, there will be a reliance on symptoms for early detection. ${ }^{1}$ Yet, the range of presenting symptoms is broad, including generally common complaints (headache, fatigue) and more specific symptoms such as loss of smell or new onset chilblains. ${ }^{6-9}$

Syndromic surveillance is a public health tool that has been used extensively to identify the beginning of seasonal influenza outbreaks in the United States ${ }^{10-12}$ and Canada, and for other viral and bacterial diseases globally. ${ }^{13}$ Where testing is incomplete, selfreported symptoms data is used to supplement confirmed case counts and estimate the true extent of disease. ${ }^{1}$ The value of syndromic surveillance is higher when syndromes are illness-specific. However, because of the broad range of symptomatic presentations observed in SARS-CoV-2-infected individuals, a highly specific definition is likely to lack sensitivity and miss most people who would be eligible for testing. ${ }^{7}$ Whereas grouping symptoms into clinical syndromes is likely to increase specificity, looking at the occurrence of any described symptom is the most sensitive way to measure all those who would be eligible for COVID-19 testing.

In Canada, phone and internet methods have been used to collect symptomatic and testing information from voluntary public participants. The primary objective of this study 
medRxiv preprint doi: https://doi.org/10.1101/2020.05.19.20107391; this version posted May 26, 2020. The copyright holder for this preprint (which was not certified by peer review) is the author/funder, who has granted medRxiv a license to display the preprint in perpetuity.

All rights reserved. No reuse allowed without permission.

was to describe the characteristics, symptoms, and self-reported testing rates of respondents across three different COVID-19 symptom and testing surveys. The one phone and two internet-based polls we studied covered varied population subsets, timeframes, and scope.

\section{METHODS}

We retrospectively analyzed existing phone and internet survey data. This study was approved by the Ethics Review Board of University Health Network.

Data Sources: Three data sources were used for this study.

The Angus Reid Institute COVID-19 symptom poll was administered online from April 16, 2020 to a randomly selected sample of Angus Reid Forum panel members (over 50,000 Canadian residents). ${ }^{14}$ Respondents were asked about symptoms during the previous month, and about SARS-CoV-2 testing. Respondents were not asked about test results.

COVID Near You (covidnearyou.org) is a web-based participatory health surveillance tool created by infectious disease epidemiologists at Boston Children's Hospital. ${ }^{15}$ This team also created Flu Near You (flunearyou.org), a similar tool for influenza symptoms, which has been validated against clinical data sources and applied to predict influenza trends. ${ }^{10-12}$ Between the Canadian launch on April $3^{\text {rd }}$ and April $26^{\text {th }}$, there were over 420,000 responses. For individuals opting to include their phone number to be contacted for follow-up surveys (12\% of responses) subsequent responses with the same age/sex/phone number were excluded $(\mathrm{N}=3,511)$. Respondents were asked to report on present symptoms, and related healthcare encounters, testing, and results. 
medRxiv preprint doi: https://doi.org/10.1101/2020.05.19.20107391; this version posted May 26, 2020. The copyright holder for this preprint (which was not certified by peer review) is the author/funder, who has granted medRxiv a license to display the preprint in perpetuity.

All rights reserved. No reuse allowed without permission.

The Forum \& Mainstreet Research poll on COVID-19 symptoms was administered by telephone and SMS (text) message to randomly selected households in Ontario in two waves: April 11-12 and April 18-19, 2020. ${ }^{16,17}$ Datasets from both survey waves were combined; only the first survey was used for households that appeared in both waves ( $N=158)$. Respondents were asked to report on new symptoms in the household over the previous week, about testing since the onset of symptoms, and test results.

Measures: Symptoms of possible COVID-19 were defined as inclusive of any of the following, where information was consistently available ( $>50 \%$ of sample was exposed to the question): fever, fatigue, runny nose, cough, aches and pains, chills/night sweats, sore throat, diarrhea, headache, shortness of breath, nausea, and loss of taste or smell. We excluded sneezing and rash as these are not described symptoms of COVID-19. We also reported on the self-reported combination of fever with either cough or shortness of breath, a COVID-like illness definition used by the World Health Organization. ${ }^{18}$ Where possible, demographic variables were categorized to facilitate qualitative comparison between surveys,.

Analysis: Due to considerable methodological differences across sources, results were analyzed separately. Where survey weights were included in sources (Angus Reid and Forum polls), we reported unweighted counts and weighted frequencies. As the COVID Near You team does not derive or use survey weights, we report unweighted counts and frequencies for results from this source. For Canada-wide data reported at the individual-level (Angus Reid Institute and COVID Near You surveys), we further report the frequency of any symptom, the syndrome of fever with cough or shortness of breath, ${ }^{18}$ and testing across demographic groups. Testing for differences was done 
medRxiv preprint doi: https://doi.org/10.1101/2020.05.19.20107391; this version posted May 26, 2020. The copyright holder for this preprint (which was not certified by peer review) is the author/funder, who has granted medRxiv a license to display the preprint in perpetuity.

All rights reserved. No reuse allowed without permission.

using Rao-Scott Chi-square tests for weighted results and Chi-square tests and Fisher exact tests (if small cells) for unweighted results, all at a two-tailed $p<0.05$ significance threshold. The data were analyzed using SAS software, version 9.4 (SAS Institute Inc., Carey, NC).

\section{RESULTS}

Angus Reid Poll- Canada-wide, April 1-6, 2020.

There were 4,240 respondents, their median age was 46.5 years (IQR 33-61), 52.0\% $(n=2,152)$ were women, nearly half had completed some college or university $(46.8 \%$, $n=2,023)$, and $13.1 \%(n=529)$ reported being a visible minority (Table 1). Completed testing was reported by $1.3 \%(n=53)$, while $2.1 \%(n=93)$ were not able to get tested, and $30.7 \%(n=1,338)$ completed a COVID-19 self-assessment through a government website or app.

Over the previous month $n=1,863(43.4 \%)$ reported at least one symptom. The most common symptoms were sore throat $(n=1229,28.6 \%)$ and cough $(n=1154,27.0 \%)$. The combination of fever with either cough or shortness of breath was reported by $6.9 \%$ of respondents $(n=295)$. Among those reporting any symptom, $2.6 \%(n=46)$ reported having received testing. Among those reporting fever with either cough or shortness of breath, 5.7\% $(n=15)$ reported having received COVID-19 testing.

More women than men reported at least one symptom ( $45.3 \%$ vs $41.2 \%, p=0.01$, Table 2). Among both men and women, older persons were less likely to report at least one symptom $(p<0.0001)$ and the combination of fever with either cough or shortness of breath ( $p=0.04$ among women, $p=0.003$ among men). Indigenous/First 
medRxiv preprint doi: https://doi.org/10.1101/2020.05.19.20107391; this version posted May 26, 2020. The copyright holder for this preprint (which was not certified by peer review) is the author/funder, who has granted medRxiv a license to display the preprint in perpetuity.

All rights reserved. No reuse allowed without permission.

Nations/Inuit/Metis had significantly higher rates of symptoms (49.3\% vs $42.9 \%, \mathrm{p}=0.04)$ and testing $(3.7 \%$ vs $1.1 \%, p=0.0004)$ than those not reporting this background. This group ( $11.0 \%$ vs $6.5 \%, p=0.005)$ and visible minorities $(10.3 \%$ vs $6.3 \%, p=0.001)$ also reported a higher rate of fever with cough or shortness of breath.

\section{COVID Near You- Canada-wide, April 3 - April 26, 2020}

After excluding duplicates, there were 409,207 responses. The median age was 42 years (IQR 33-54) and 58.0\% $(n=237,150)$ were women (Table 1). Testing was reported in $0.2 \%(n=612)$ of responses, and $0.4 \%(n=1,479)$ reported seeing a health professional. Positive test results were reported in $0.03 \%(n=105)$; some $0.1 \%(n=213)$ reported that they were still waiting for their result. Among all respondents, $0.1 \%$ $(n=313)$ reported travel outside Canada in the previous two weeks and $0.1 \%(n=324)$ reported contact with a known case of COVID-19.

The overall prevalence of symptoms was $1.6 \%(n=6,746)$ and the most common symptoms were fatigue $(n=3,982,1.0 \%)$, cough $(n=3,416,0.8 \%)$ and headaches $(n=3,406,0.8 \%)$. The combination of fever with either cough or shortness of breath was reported by $0.2 \%$ of respondents $(n=758)$. Among those reporting any symptom, $8.9 \%$ $(n=598)$ reported being tested. Among those reporting fever with cough or shortness of breath, $21.0 \%(n=159)$ reported being tested. Of the symptomatic who were tested, $17.2 \%(n=103)$ reported a positive result.

More women than men reported at least one symptom $(2.0 \%$ vs $1.2 \%, p<0.001$, Table $2)$, and were tested $(0.2 \%$ vs $0.1 \%, p<0.001)$; men and women had similar rates of positive test results (0.3\% vs $0.2 \%, p=0.44)$. Among both women and men, younger or 
medRxiv preprint doi: https://doi.org/10.1101/2020.05.19.20107391; this version posted May 26, 2020. The copyright holder for this preprint (which was not certified by peer review) is the author/funder, who has granted medRxiv a license to display the preprint in perpetuity. All rights reserved. No reuse allowed without permission.

middle-aged groups were more likely to report symptoms than older groups $(p<0.001)$. Among men, those over age 75 were more likely to have been tested $(p=0.003)$. The rate of symptoms varied significantly across provinces - reporting at least one symptom was most common in British Columbia (2.1\%) and Ontario (2.0\%, $\mathrm{p}<0.001)$, yet reported testing rates were the highest in Nova Scotia (0.4\%) and Saskatchewan $(0.3 \%$, $\mathrm{p}<0.001)$

Forum \& Mainstreet Research phone poll- Ontario, April 11-12 and April 18-19, 2020

There were 9,147 unique households surveyed, and $41.7 \%(n=4,165)$ consisted of at least 3 residents (Table 1). The survey respondents were more often women $(53.3 \%$, $n=4,931)$ than men. Completed testing was reported by $3.2 \%$ of all households $(n=299)$, and positive test results by $0.4 \%(n=43)$. In addition, $0.5 \%(n=50)$ were still awaiting test results.

The overall prevalence of any new symptom in the previous week was $14.9 \%(n=1,385)$. The most common symptoms reported were headache $(n=662,7.0 \%)$, sore throat $(n=377,3.9 \%)$ and diarrhea $(N=345,3.8 \%)$. The combination of fever with either cough or shortness of breath within the same household was reported by $0.8 \%(\mathrm{n}=82)$. Among those with any symptom, $6.5 \%(n=94)$ reported that a household member had been tested. Among those with fever and either cough or shortness of breath, 37.5\% ( $n=31)$ reported that a household member had been tested. Positive test results were reported for $26.5 \%(n=25)$ of all symptomatic households tested. 
medRxiv preprint doi: https://doi.org/10.1101/2020.05.19.20107391; this version posted May 26, 2020. The copyright holder for this preprint (which was not certified by peer review) is the author/funder, who has granted medRxiv a license to display the preprint in perpetuity.

\section{DISCUSSION}

In this study of syndromic surveillance data from three different survey sources, we find that described symptoms of COVID-19 are commonly reported by Canadian respondents. Specifically, $1.6 \%$ of respondents reported a symptom on the day of response, $15 \%$ of Ontario households had a new symptom in the previous week, and 43\% of Canada-wide respondents had a symptom during March-early April 2020. Across the three studies, SARS-CoV-2-testing was reported in 2-9\% of symptomatic responses, with a positive test rate among the symptomatic who were tested of $17 \%$ in COVID Near You and 27\% in the Forum Research poll. The three survey sources differed in geography (one covered only Ontario), time period (March to end of April 2020), and their representativeness across different demographic variables. Yet, after considering differences in the time window addressed with survey questions (present day, past week, past month), results were mostly consistent.

In two different polls, women were more likely to report at least one symptom. In one poll, women were more likely to report testing. In Ontario, more women than men have been tested for SARS-CoV-2, yet men were more likely to have a positive test result. ${ }^{19}$ Although the higher testing rate among women could reflect their greater presence in the healthcare sector, our findings also raise the possibility that women are more likely to report COVID-19-like symptoms. We further found that older groups of both genders were less likely to report at least one symptom. We found that Indigenous/First Nations/Inuit/Metis individuals reported a higher rate of symptoms and testing, and that visible minorities reported higher rates of fever with cough or shortness of breath. Residents of Indigenous communities are a priority group for SARS-CoV-2 testing. ${ }^{5}$ 
medRxiv preprint doi: https://doi.org/10.1101/2020.05.19.20107391; this version posted May 26, 2020. The copyright holder for this preprint (which was not certified by peer review) is the author/funder, who has granted medRxiv a license to display the preprint in perpetuity.

All rights reserved. No reuse allowed without permission.

Notably, we did not identify significant differences in the frequency of possible COVID19 symptoms across income or education groups. A recent report from the province of Ontario also did not identify a consistent difference in testing rates across socioeconomic groups, although neighborhoods with higher ethnic concentration had a significantly higher rate of test positivity. ${ }^{20}$

An important consideration in interpreting our findings is that many people with reported symptoms will not have COVID-19; conditions ranging from stress-related headaches and allergies to undiagnosed malignancies could also cause these same symptoms. Conversely, an estimated $20-75 \%$ of COVID-19 infected individuals are asymptomatic or minimally symptomatic..$^{3,4,21,22}$ Using a only a more restrictive symptomatic definition such as fever with either cough or shortness of breath would miss many potential cases. Similarly, a recently developed algorithm that combines loss of smell or taste, fatigue, skipped meals, and cough, was only $65 \%$ sensitive for a positive test result. ${ }^{7}$ To better understand current testing rates, we opted to use a broad symptom definition. This definition essentially includes anyone who would be eligible for testing on the basis of symptoms. To facilitate comparison, we also reported the proportion with fever and either cough or shortness of breath, a syndromic definition used by the World Health Organization. $^{18}$ The weekly rate of household-level combination of fever with cough or shortness of breath in this study (Forum Research poll of Ontario in mid-April: $0.8 \%$ ) was comparable to that obtained by the Public Health Agency of Canada's FluWatchers for the combination of cough and fever in early April $2020(0.5 \%){ }^{23}$

There have been no previous reports of COVID-19 symptoms among the broader Canadian population published in the peer-reviewed literature. Our study provides 
medRxiv preprint doi: https://doi.org/10.1101/2020.05.19.20107391; this version posted May 26, 2020. The copyright holder for this preprint (which was not certified by peer review) is the author/funder, who has granted medRxiv a license to display the preprint in perpetuity.

All rights reserved. No reuse allowed without permission.

essential information the prevalence of such symptoms, and the proportion of symptomatic persons being tested. Major strengths of this study are its inclusion of selfreported data from three distinct sources, covering March-April 2020. The consistency of our findings with published public health data suggests it is representative of the general population. Finally, the information we provide allows for a more complete picture of COVID-19 in Canada than just that which manifests through healthcare encounters. Lower barriers to diagnostic testing are essential given the growing understanding that COVID-19 can present with myriad symptoms. This will be helpful in identifying and isolating cases and preventing outbreaks as public health measures are lifted.

Our study also has several limitations. The variable time frames used in the three data sources complicate cross-study comparison, and longer time periods of self-report (e.g. "in the past month") may lead to higher levels of recall bias than shorter time periods. Similarly, household-level reporting does not easily compare to individual report, and combining symptoms experienced within a household may erroneously attribute all those symptoms to the same individual- these are important caveats. Furthermore, survey questions varied in terms of symptoms covered and inclusion of questions relating to healthcare encounters or testing results. Sample sizes were also quite small within subgroups, particularly when looking at those that reported testing or testing positive. Although the Angus Reid and Forum Research polls had a random sampling strategy, respondents on COVID Near You were self-selected, and so it was important to compare their characteristics, symptom reports, and testing rates to those obtained in the other two studies. Finally, despite their overall higher risk for COVID-19, those 
medRxiv preprint doi: https://doi.org/10.1101/2020.05.19.20107391; this version posted May 26, 2020. The copyright holder for this preprint (which was not certified by peer review) is the author/funder, who has granted medRxiv a license to display the preprint in perpetuity. All rights reserved. No reuse allowed without permission.

residing in long-term care and other institutional settings are likely not represented in these data sources which focus on community-dwelling residents of Canada.

This study contributes essential data on the prevalence of COVID-19-related symptoms in Canada, and the proportion of symptomatic persons being tested. This information complements public health-reported data on testing numbers and confirmed cases in Canada. We find that across three unique symptom surveys, less than $10 \%$ of those with symptoms reported having been tested for SARS-CoV-2 in March-April 2020. Our findings highlight the significant room to expand testing among community-dwelling residents of Canada. We have also identified groups with higher symptom prevalence (women, younger age groups, Indigenous/First Nations/Inuit/Métis)- information which can be used to refine testing strategies and outreach. Syndromic surveillance data such as these can supplement public health reports and provide much-needed context to gauge the adequacy of current SARS-CoV-2 testing rates.

Acknowledgements: We thank Boston Children's Hospital, the Angus Reid Institute, Forum Research and Mainstreet Research for providing the data used in this study. Boston Children's Hospital, the Angus Reid Institute, Forum Research and Mainstreet Research bear no responsibility for the analyses or interpretations of the data presented here.

Funding: this study received no specific funding. 
medRxiv preprint doi: https://doi.org/10.1101/2020.05.19.20107391; this version posted May 26, 2020. The copyright holder for this preprint (which was not certified by peer review) is the author/funder, who has granted medRxiv a license to display the preprint in perpetuity.

All rights reserved. No reuse allowed without permission.

\section{REFERENCES}

1. Lipsitch M, Swerdlow DL, Finelli L. Defining the Epidemiology of Covid-19 - Studies Needed. New England Journal of Medicine. 2020;382(13):1194-1196.

2. Gandhi RT, Lynch JB, Del Rio C. Mild or Moderate Covid-19. The New England journal of medicine. 2020.

3. Mizumoto K, Kagaya K, Zarebski A, Chowell G. Estimating the asymptomatic proportion of coronavirus disease 2019 (COVID-19) cases on board the Diamond Princess cruise ship, Yokohama, Japan, 2020. Euro Surveill. 2020;25(10):2000180.

4. Buitrago-Garcia DC, Egli-Gany D, Counotte MJ, et al. The role of asymptomatic SARSCoV-2 infections: rapid living systematic review and meta-analysis. medRxiv. 2020:2020.2004.2025.20079103.

5. City of Toronto. Toronto Region COVID-19 Assessment Centres. 2020; https://www.toronto.ca/home/covid-19/covid-19-health-advice/covid-19-assessmentcentres/. Accessed May 9, 2020.

6. Huang L-S, Li L, Dunn L, He M. Taking Account of Asymptomatic Infections in Modeling the Transmission Potential of the COVID-19 Outbreak on the Diamond Princess Cruise Ship. medRxiv. 2020:2020.2004.2022.20074286.

7. Menni C, Valdes AM, Freidin MB, et al. Real-time tracking of self-reported symptoms to predict potential COVID-19. Nature Medicine. 2020.

8. Spinato G, Fabbris C, Polesel J, et al. Alterations in Smell or Taste in Mildly Symptomatic Outpatients With SARS-CoV-2 Infection. JAMA. 2020.

9. Landa N, Mendieta-Eckert M, Fonda-Pascual P, Aguirre T. Chilblain-like lesions on feet and hands during the COVID-19 Pandemic. International Journal of

Dermatology.n/a(n/a).

10. Baltrusaitis K, Brownstein JS, Scarpino SV, et al. Comparison of crowd-sourced, electronic health records based, and traditional health-care based influenza-tracking systems at multiple spatial resolutions in the United States of America. BMC Infect Dis. 2018;18(1):403.

11. Baltrusaitis K, Santillana M, Crawley AW, Chunara R, Smolinski M, Brownstein JS. Determinants of Participants' Follow-Up and Characterization of Representativeness in Flu Near You, A Participatory Disease Surveillance System. JMIR public health and surveillance. 2017;3(2):e18.

12. Brownstein JS, Chu S, Marathe A, et al. Combining Participatory Influenza Surveillance with Modeling and Forecasting: Three Alternative Approaches. JMIR public health and surveillance. 2017;3(4):e83.

13. Smolinski MS, Crawley AW, Olsen JM, Jayaraman T, Libel M. Participatory Disease Surveillance: Engaging Communities Directly in Reporting, Monitoring, and Responding to Health Threats. JMIR public health and surveillance. 2017;3(4):e62.

14. Angus Reid Institute. The incidence of COVID-19 infection in Canada? 2020.

15. COVID Near You. https://www.covidnearyou.org/\#!/. Accessed May 8, 2020.

16. Forum \& Mainstreet Research. COVID-19 Symptom Study- Ontario. 2020; https://www.mainstreetresearch.ca/one-fifth-of-ontario-households-have-one-or-moresymptoms-of-covid-19/. Accessed May 8, 2020.

17. Forum Research \& Mainstreet Research. COVID-19 Study Ontario- Wave 2. 2020; https://www.mainstreetresearch.ca/incidence-of-covid-19-symptoms-down-in-ontariofrom-last-week/. Accessed May 8, 2020.

18. World Health Organization. Global surveillance for COVID-19 caused by human infection with COVID-19 virus. 2020; https://www.who.int/docs/default- 
medRxiv preprint doi: https://doi.org/10.1101/2020.05.19.20107391; this version posted May 26, 2020. The copyright holder for this preprint

(which was not certified by peer review) is the author/funder, who has granted medRxiv a license to display the preprint in perpetuity.

All rights reserved. No reuse allowed without permission.

source/coronaviruse/global-surveillance-for-covid-v-19-final200321-rev.pdf. Accessed May 8, 2020.

19. Stall NM, Wu W, Lapointe-Shaw L, Fisman D, Hillmer M, Rochon PA. Sex-specific differences in COVID-19 testing, cases and outcomes: a population-wide study in Ontario, Canada. medRxiv. 2020:2020.2004.2030.20086975.

20. Chung H, Fung K, Ferreira-Legere L, et al. COVID-19 Laboratory Testing in Ontario: Patterns of Testing and Characteristics of Individuals Tested, as of April 30, 2020. 2020; https://www.ices.on.ca/Publications/Atlases-and-Reports/2020/COVID-19-LaboratoryTesting-in-Ontario. Accessed May 11, 2020.

21. Arons MM, Hatfield KM, Reddy SC, et al. Presymptomatic SARS-CoV-2 Infections and Transmission in a Skilled Nursing Facility. New England Journal of Medicine. 2020.

22. Day M. Covid-19: identifying and isolating asymptomatic people helped eliminate virus in Italian village. BMJ. 2020;368:m1165.

23. Public Health Agency of Canada. Fluwatchers. 2019. 
medRxiv preprint doi: https://doi.org/10.1101/2020.05.19.20107391; this version posted May 26, 2020. The copyright holder for this preprint (which was not certified by peer review) is the author/funder, who has granted medRxiv a license to display the preprint in perpetuity. All rights reserved. No reuse allowed without permission.

Table 1: Self-reported characteristics of respondents in each of the three data sources.

\begin{tabular}{|c|c|c|c|}
\hline & $\begin{array}{c}\text { Angus Reid } \\
\text { Institute } \\
N=4,240 \\
\text { individuals }\end{array}$ & $\begin{array}{l}\text { COVID Near } \\
\text { You } \\
\mathrm{N}=409,207 \\
\text { responses }\end{array}$ & $\begin{array}{c}\text { Forum/Mainstreet } \\
\mathrm{N}=9,147 \\
\text { Ontario } \\
\text { households }\end{array}$ \\
\hline $\begin{array}{l}\text { Age group of } \\
\text { respondent, } \mathbf{n}(\%) \\
\text { Under } 35 \text { years } \\
35-54 \\
55-64 \\
65-74 \\
75+\text { years }\end{array}$ & $\begin{array}{c}1,197(28.3) \\
1,491(34.6) \\
755(17.9) \\
618(14.8) \\
179(4.4)\end{array}$ & $\begin{array}{c}114389(28.0) \\
195140(47.7) \\
64765(15.8) \\
29855(7.3) \\
5057(1.2)\end{array}$ & $\begin{array}{l}1,288(13.0) \\
2,854(31.2) \\
2,119(24.0) \\
1,798(19.6) \\
1,088(12.2)\end{array}$ \\
\hline $\begin{array}{l}\text { Gender of respondent, } \mathbf{n} \\
(\%) \\
\text { Female } \\
\text { Male } \\
\text { Other/No response }\end{array}$ & $\begin{array}{c}2,152(52.0) \\
2,066(47.6) \\
22(0.4)\end{array}$ & $\begin{array}{c}237,150(58.0) \\
164,487(40.2) \\
7,570(1.8)\end{array}$ & $\begin{array}{c}4,931(53.3) \\
4,044(45.0) \\
172(1.7)\end{array}$ \\
\hline $\begin{array}{l}\text { Household Income (\$), n } \\
\text { (\%) } \\
\text { Under } 25,000 \\
25,000-<50,000 \\
50,000-<100,000 \\
100,000-<150,000 \\
150,000-<200,000 \\
>200,000 \\
\text { Don't know/rather not say }\end{array}$ & $\begin{array}{c}422(9.7) \\
761(17.5) \\
1,296(30.3) \\
762(18.3) \\
312(7.7) \\
166(4.1) \\
521(12.4)\end{array}$ & - & $\begin{array}{c}842(7.3)^{*} \\
2,719(24.4)^{*} \\
1,937(20.3)^{\star} \\
1,860(28.4)^{*} \\
1,789(19.6)^{*}\end{array}$ \\
\hline $\begin{array}{l}\text { Highest Level of } \\
\text { Education of } \\
\text { Respondent, } \mathbf{n}(\%) \\
\text { Secondary or less } \\
\text { Some college or university } \\
\text { Completed undergraduate } \\
\text { Post-graduate degree }\end{array}$ & $\begin{array}{c}1,043(25.1) \\
2,023(46.8) \\
819(19.4) \\
355(8.8)\end{array}$ & - & $\begin{array}{l}1,829(18.3) \\
3,335(34.7) \\
2,405(27.6) \\
1,578(19.4)\end{array}$ \\
\hline $\begin{array}{l}\text { Respondent is } \\
\text { Indigenous/First } \\
\text { Nations/Inuit/Métis, n (\%) }\end{array}$ & $321(7.3)$ & - & - \\
\hline $\begin{array}{l}\text { Respondent is a visible } \\
\text { minority, } \mathrm{n}(\%)\end{array}$ & $529(13.1)$ & - & - \\
\hline
\end{tabular}




\begin{tabular}{|l|c|c|c|}
\hline Household size, $\mathbf{n}(\%)$ & & - & $1,620(23.9)$ \\
1 & $693(15.8)$ & & $3,362(34.5)$ \\
2 & $1,637(38.1)$ & & $1,526(16.0)$ \\
3 & $790(19.0)$ & & $1,525(15.3)$ \\
4 & $715(17.3)$ & & $1,114(10.4)$ \\
$5+$ & $405(9.8)$ & & \\
\hline Province, n (\%) & & & \\
Alberta & $422(11.2)$ & $55,257(13.5)$ & \\
BC & $788(13.1)$ & $70,634(17.3)$ & \\
Manitoba & $259(3.5)$ & $15,239(3.7)$ & \\
New Brunswick & $81(1.8)$ & $5,765(1.4)$ & \\
Newfoundland/Labrador & $73(1.8)$ & $1,786(0.4)$ & \\
Nova Scotia & $147(3.4)$ & $13,220(3.2)$ & \\
Ontario & $1,200(37.7)$ & $214,300(52.4)$ & \\
PEl & $9(0.2)$ & $571(0.1)$ & \\
Quebec & $1,010(24.1)$ & $20,344(5.0)$ & \\
Saskatchewan & $251(3.1)$ & $11,777(2.9)$ & \\
Northwest Territories & 0 & $102(0.0)$ & \\
Yukon & 0 & $176(0.0)$ & \\
Nunavut & 0 & $21(0.0)$ & \\
\hline
\end{tabular}

* The household income categories for the Forum/Mainstreet poll are: Under 20,000, $20,000-60,000,60,000-100,000,>100,000$, and rather not say. 
medRxiv preprint doi: https://doi.org/10.1101/2020.05.19.20107391; this version posted May 26, 2020. The copyright holder for this preprint (which was not certified by peer review) is the author/funder, who has granted medRxiv a license to display the preprint in perpetuity. All rights reserved. No reuse allowed without permission.

Table 2: Prevalence of symptoms and testing within sociodemographic groups in Angus Reid poll, April 1-6, 2020. p-values for within-group differences are at the top of each cell. Cells $<6$ have been suppressed (denoted with a "-"). NA=not applicable (p-value could not be calculated due to zero cells and weighted data)

\begin{tabular}{|c|c|c|c|}
\hline & $\begin{array}{c}\text { Any symptom, } \\
\mathrm{n}(\%)\end{array}$ & $\begin{array}{l}\text { Fever + (cough } \\
\text { OR shortness of } \\
\text { breath), } n(\%)\end{array}$ & $\begin{array}{l}\text { Reported testing, } \mathbf{n} \\
(\%)\end{array}$ \\
\hline $\begin{array}{l}\text { Women, All } \\
\text { Under } 35 \text { years } \\
35-54 \\
55-64 \\
65-74 \\
75+\text { years }\end{array}$ & $\begin{array}{l}991(45.3) \\
p<0.0001 \\
335(53.5) \\
370(49.1) \\
148(37.3) \\
106(34.0) \\
32(33.8)\end{array}$ & $\begin{array}{c}159(7.2) \\
p=0.04 \\
58(8.8) \\
63(8.1) \\
22(6.4) \\
13(4.2) \\
\quad-\end{array}$ & $\begin{array}{c}26(1.2) \\
N A \\
8(1.5) \\
11(1.5) \\
- \\
- \\
0(0)\end{array}$ \\
\hline $\begin{array}{l}\text { Men, All } \\
\text { Under } 35 \text { years } \\
35-54 \\
55-64 \\
65-74 \\
75+\text { years }\end{array}$ & $\begin{array}{l}861(41.2) \\
p<0.0001 \\
285(50.0) \\
331(44.1) \\
127(35.3) \\
91(28.3) \\
27(30.6)\end{array}$ & $\begin{array}{c}133(6.4) \\
p=0.003 \\
52(9.7) \\
49(6.2) \\
18(5.3) \\
11(2.9) \\
\quad-\end{array}$ & $\begin{aligned} 26 & (1.2) \\
p & =0.94 \\
6 & (1.1) \\
12 & (1.5) \\
& - \\
& - \\
& -\end{aligned}$ \\
\hline $\begin{array}{l}\text { Household income }(\$) \\
\text { Under } 25,000 \\
25,000-<50,000 \\
50,000-<100,000 \\
100,000-<150,000 \\
150,000-<200,000 \\
>200,000 \\
\text { Don't know/would rather } \\
\text { not say }\end{array}$ & $\begin{array}{c}p=0.36 \\
197(45.9) \\
335(43.7) \\
580(44.4) \\
340(43.1) \\
142(45.6) \\
65(39.6) \\
204(38.9)\end{array}$ & $\begin{array}{l}p=0.54 \\
39(8.7) \\
50(6.4) \\
97(7.6) \\
52(6.7) \\
15(5.1) \\
10(6.7) \\
32(5.8)\end{array}$ & $\begin{array}{c}p=0.26 \\
- \\
8(1.1) \\
15(1.3) \\
12(1.4) \\
8(2.7) \\
- \\
-\end{array}$ \\
\hline $\begin{array}{l}\text { Highest Level of } \\
\text { Education } \\
\text { Secondary or less } \\
\text { Some college or } \\
\text { university } \\
\text { Completed } \\
\text { undergraduate } \\
\text { Post-graduate degree }\end{array}$ & $\begin{array}{c}p=0.13 \\
437(40.6) \\
903(44.6) \\
374(45.1) \\
149(41.2)\end{array}$ & $\begin{array}{c}p=0.80 \\
75(7.1) \\
147(7.1) \\
51(6.4) \\
22(5.8)\end{array}$ & $\begin{array}{c}p=0.99 \\
11(1.3) \\
25(1.3) \\
11(1.2) \\
6(1.4)\end{array}$ \\
\hline $\begin{array}{l}\text { Indigenous/First } \\
\text { nations/Inuit/Métis }\end{array}$ & $\begin{array}{c}p=0.04 \\
161(49.3)\end{array}$ & $\begin{array}{l}p=0.005 \\
36(11.0)\end{array}$ & $\begin{array}{c}p=0.0004 \\
11(3.7)\end{array}$ \\
\hline
\end{tabular}




\begin{tabular}{|l|c|c|c|} 
Visible minority & $\begin{array}{c}p=0.31 \\
245(45.5)\end{array}$ & $\begin{array}{c}p=0.001 \\
56(10.3)\end{array}$ & $\begin{array}{c}p=0.10 \\
10(2.1)\end{array}$ \\
\hline Province* $^{*}$ & $p=0.25$ & $p=0.41$ & $N A$ \\
Alberta & $191(44.6)$ & $33(7.5)$ & - \\
British Columbia & $359(45.7)$ & $54(6.6)$ & $8(1.2)$ \\
Manitoba & $124(47.3)$ & $26(10.7)$ & - \\
New Brunswick & $42(51.5)$ & $8(9.2)$ & - \\
Newfoundland/Labrador & $26(36.1)$ & - & - \\
Nova Scotia & $67(46.8)$ & $7(5.1)$ & $20(1.1)$ \\
Ontario & $499(41.4)$ & $88(7.3)$ & - \\
Quebec & $435(43.1)$ & $59(5.7)$ & \\
Saskatchewan & $115(45.9)$ & $15(6.1)$ & \\
\hline
\end{tabular}

*Prince Edward Island results were suppressed due to small cells ( $<6$ observations). 
Table 3: Prevalence of self-reported symptoms, testing and positive test results within age, gender and province groups in COVID Near You poll, April 4-26, 2020. p-values for within-group differences are at the top of each cell. Cells $<6$ have been suppressed (denoted with a "-").

\begin{tabular}{|c|c|c|c|c|}
\hline & $\begin{array}{c}\text { Any } \\
\text { symptom, } \\
\text { n (\%) }\end{array}$ & $\begin{array}{l}\text { Fever + (cough } \\
\text { OR shortness of } \\
\text { breath), n (\%) }\end{array}$ & $\begin{array}{c}\text { Reported } \\
\text { testing, n } \\
(\%)\end{array}$ & $\begin{array}{l}\text { Reported } \\
\text { positive test } \\
\text { result, } \mathrm{n}(\%)\end{array}$ \\
\hline $\begin{array}{l}\text { Women, All } \\
\text { Under } 35 \text { years } \\
35-54 \\
55-64 \\
65-74 \\
75+\text { years }\end{array}$ & $\begin{array}{c}4,672(2.0) \\
p<0.001 \\
1,335(1.9) \\
2,229(2.0) \\
807(2.2) \\
271(1.7) \\
30(1.5)\end{array}$ & $\begin{array}{l}511(0.2) \\
p=0.64 \\
141(0.2) \\
247(0.2) \\
82(0.2) \\
34(0.2) \\
7(0.3)\end{array}$ & $\begin{array}{c}432(0.2) \\
p=0.34 \\
132(0.2) \\
216(0.2) \\
55(0.2) \\
24(0.2) \\
-\end{array}$ & $\begin{array}{c}61(0.03) \\
p=0.014 \\
19(0.03) \\
27(0.02) \\
8(0.02) \\
- \\
-\end{array}$ \\
\hline $\begin{array}{l}\text { Men, All } \\
\text { Under } 35 \text { years } \\
35-54 \\
55-64 \\
65-74 \\
75+\text { years }\end{array}$ & $\begin{array}{c}1,904(1.2) \\
p<0.001 \\
562(1.4) \\
870(1.1) \\
320(1.2) \\
118(0.9) \\
34(1.2)\end{array}$ & $\begin{array}{l}210(0.1) \\
p=0.003 \\
76(0.2) \\
84(0.1) \\
37(0.1) \\
10(0.1) \\
3(0.1)\end{array}$ & $\begin{array}{c}158(0.1) \\
p=0.003 \\
54(0.1) \\
68(0.1) \\
19(0.1) \\
10(0.1) \\
7(0.3)\end{array}$ & $\begin{array}{c}36(0.02) \\
p=0.36 \\
9(0.02) \\
16(0.02) \\
- \\
- \\
-\end{array}$ \\
\hline $\begin{array}{l}\text { Province* } \\
\text { Alberta } \\
\text { BC } \\
\text { Manitoba } \\
\text { New Brunswick } \\
\text { Newfoundland/Labr } \\
\text { ador } \\
\text { Nova Scotia } \\
\text { Ontario } \\
\text { PEI } \\
\text { Quebec } \\
\text { Saskatchewan }\end{array}$ & $\begin{array}{c}p<0.001 \\
868(1.6) \\
1483(2.1) \\
242(1.6) \\
91(1.6) \\
26(1.5) \\
\\
269(2.0) \\
3336(1.6) \\
7(1.2) \\
249(1.2) \\
170(1.4)\end{array}$ & $\begin{array}{c}p<0.001 \\
68(0.1) \\
218(0.3) \\
25(0.2) \\
8(0.1) \\
\quad- \\
\\
18(0.1) \\
377(0.2) \\
- \\
22(0.1) \\
18(0.2)\end{array}$ & $\begin{array}{c}p<0.001 \\
97(0.2) \\
95(0.1) \\
16(0.1) \\
9(0.2) \\
- \\
\\
49(0.4) \\
291(0.1) \\
- \\
22(0.1) \\
31(0.3)\end{array}$ & $\begin{array}{c}p=0.08 \\
7(0.01) \\
21(0.03) \\
0(0) \\
0(0) \\
- \\
- \\
67(0.03) \\
0(0) \\
- \\
-\end{array}$ \\
\hline
\end{tabular}

${ }^{*}$ Due to small cell sizes $(<6)$, results for Yukon, Northwest Territories and Nunavut were suppressed. 